\title{
POSTOPERATIVE SORE THROAT RELATED TO TRACHEAL TUBE CUFF DESIGN
}

\author{
Ola Stenqvist and Krister Nilsson
}

\begin{abstract}
Recent reports of the incidence of postoperative sore throat following anaesthesia with tracheal intubation have claimed that low volume high pressure cuffs are preferable to those with high volume and low pressure. In this study similar methods were used for evaluating postoperative sore throat. Randomly selected tracheal tubes were used in 56 patients undergoing elective abdominal surgery, followed by direct questioning about sore throat on the first postoperative day. The incidence of postoperative sore throat was 41 per cent with high volume low pressure cuffed tubes and 55 per cent with low volume high pressure cuffed tubes. This difference is not statistically significant, but the tendency of the results is contradictory to those published earlier. The incidence of postoperative sore throat varies greatly if direct or indirect questioning is used and also varies between studies using the same method of questioning. Therefore the validity of this method for evaluating the influence of cuff design must be questioned. Postoperative sore throat is a symptom caused by many factors, such as the intubation procedure and the use of stylets or lubricants. The incidence of postoperative sore throat does not necessarily reflect damage caused by the tracheal tube cuff.
\end{abstract}

KEY WORDS: COMPLICATIONS, postoperative sore throat; EQUIPMENT, tracheal tube cuff design.

TRACHEAL DAMAgE after long term intubation with permanent severe damage to a small number of patients, led to improvement in cuff design. ' Interest has then been focused on short term intubation $^{2-4}$ and postoperative sore throat ${ }^{7-9}$. Postoperative sore throat (PST) is a quantitatively large problem - little but reversible damage to a large number of patients. PST has been evaluated by interviewing patients the day after operation. Wolfson ${ }^{5}$ reported an incidence of PST of 18.4 per cent using direct questioning, Hartsell and Stephen 6.7 per cent using indirect questioning, while Loeser, et $a l^{7}$ had a PST incidence of 24 per cent with low volume cuffs and 58 per cent with high volume cuffs using direct questioning.

Loeser, et al ${ }^{7-9}$ have investigated the relation between PST and cuff pressure, lubricant and cuff-tracheal contact area. They conclude that lubricant and high volume cuffs result in a higher frequency of PST, the best results being achieved with unlubricated low volume high pressure cuffs. These findings are in opposition with

Ola Stenqvist, M.D., Krister Nilsson, M.D., Department of Anaesthesiology, Sahlgren's Hospital and East Hospital, Gothenburg, Sweden.

Correspondence and reprint requests to: Ola Stenqvist, M.D., Department of Anaesthesiology, Sahlgren's Hospital, S-413 45 GOTHENBURG, SWEDEN.

Can. Anaesth. Soc. J., vol. 29, no. 4, July 1982 results from clinical investigations of long term intubation where high volume cuffs have resulted in less tracheal damage than low volume cuffs. ${ }^{10}$ These results imply that the pressure on the tracheal mucosa plays an important role in the development of tracheal damage. Nordin ${ }^{11}$ and Romanus ${ }^{12}$ have shown that ischaemia from pressure on mucosa leads to severe damage after less than four hours. Stenqvist ${ }^{13}$ showed that a cuff-tracheal wall pressure of 40 per cent of the mean arterial pressure caused ischaemia over the cartilages. To further elucidate the incidence of PST a high volume low pressure cuffed tube was compared with a low volume high pressure cuffed tube.

\section{Methods}

The Portex Blue Line of $8 \mathrm{~mm}$ inner diameter (PBL 8) was used as a representative low volume cuffed tube and a National Catheter Mallincrodt Hilo of $8 \mathrm{~mm}$ inner diameter as a representative high volume cuffed tube. Both tubes were in routine use at this hospital. The PBL 8 was used in 29 patients ( 10 males and 19 females), and a Hilo 8 in 27 patients ( 9 males and 18 females). The type of tracheal tube was selected randomly for each patient. The patients underwent elective abdominal operations (cholesystectomies, hernias, hysterectomies). The average duration of 
intubation was 118 minutes in the PBL 8 and 122 minutes in the Hilo 8 groups respectively.

The cuff-tracheal wall contact area was measured according to Loeser, et al. ${ }^{7}$ in a plexiglass tube of $20 \mathrm{~mm}$ inner diameter when sealing against a pressure of $15 \mathrm{~cm} \mathrm{H}_{2} \mathrm{O}$. The PBL 8 had a contact area of $11 \mathrm{~cm}^{2}$ and the Hilo 8 of $20 \mathrm{~cm}^{2}$.

Anaesthesia was induced with thiopentone $3-4 \mathrm{mg} \cdot \mathrm{kg}^{-1}$. The trachea was intubated following succinylcholine $1 \mathrm{mg} \cdot \mathrm{kg}^{-1}$ without the use of stylet or lubricants. Anaesthesia was maintained with nitrous oxide-oxygen (70:30) supplemented regularly with fentanyl during the operation. Muscle relaxation was maintained with pancuronium and the patients were ventilated with a non-rebreathing ventilator of the bag in bottle type (AGA UV 705) with a humidifier (Fisher \& Paykel). Gas temperature at the tracheal tube was $36^{\circ} \mathrm{C}$.

The tracheal tube cuffs were inflated with the inspired gas mixture to avoid additional inflation during anaesthesia. ${ }^{3-14}$ The cuffs were only inflated until no leak was audible with a stethoscope over the trachea.

On the first postoperative day the patients were interviewed by an anaesthetist who did not know what tube had been used. Direct questions were used about scratchy or sore throat, or if the patients felt hoarse. Patients needing stomach tubes were omitted. The answers were not graded but only recorded as postoperative sore throat or not

\section{Results}

Fifty-five per cent $(16 / 29)$ of the patients intubated with PBL 8 and 41 per cent $(11 / 27)$ of the Hilo 8 group had PST. The difference in incidence of PST was not significant (Chisquare).

\section{Discussion}

The difference in PST incidence is not significant when using the Chi-square test on the actual incidence figures. However, if the Chisquare test is applied to the incidence of PST expressed as per cent of the total material, which seems to be the method used by Loeser, et al., there is a significant difference $(p<0.05)$, with high volume cuffs causing less PST in our study. It should be emphasized that using incidence figures expressed in per cent has the effect that, if the actual material is less than 100 , it is increased to 100 in the calculation, i.e. the material on which calculations are based is larger than the actual material. Loeser, et al ${ }^{9}$ showed, though, that the low volume cuffs were causing significantly lower PST than high volume cuffs with this statistical method.

According to Loeser, et al. ${ }^{7-9}$ the contact area is one of the main factors in PST, a smaller contact area giving less PST. The PBL 8 had a contact area of $11 \mathrm{~cm}^{2}$ and the HiLo $8,20 \mathrm{~cm}^{2}$. Thus, the PBL 8 should have a lower incidence of PST than the HiLo 8 if contact area is the most important factor. This was not the case in our investigation. There are probably several explanations of the contradictory results compared with those of Loeser, et al. ${ }^{9}$ The interview technique may be too blunt an instrument to evaluate and differentiate the pathogenetic factors in PST. This is indicated by the wide variations in results by other authors. ${ }^{5-9}$

The favourable effects of reducing the pressure from the cuff on the tracheal wall has been well established in long term intubation. ${ }^{10} \mathrm{In}$ experimental animal studies the effect of short pressure periods (less than 4 hours) have shown that both the magnitude and the duration of pressure are important factors in damaging a mucosa. ${ }^{12}$ Ischaemia over the cartilages is achieved at a cuff-tracheal wall pressure of 40 per cent of the mean arterial pressure but at pressures above $20 \mathrm{~mm} \mathrm{Hg}$ the mucosal micro-circulation is already impaired. ${ }^{13}$ Nordin $^{3}$ showed that denudation of the epithelium covering the cartilages occurred after less than two hours of ischaemic pressure in the rabbit. It is evident that even moderate pressures may severely damage the tracheal mucosa. Our results in this investigation agree with these short term effects of experimental intubation as well as with the findings in long term clinical intubation.

Other factors may be important in explaining why our results are diverging from those of Loeser, et al., such as intubation technique, stylets - no stylets, spontaneous ventilation controlled ventilation, and differences in cuff material. In long term tracheal intubation, the intubation procedure itself plays a relatively small part in causing damage compared to the effect of cuff pressure. In short term intubation, as for operations, the impact of the intubation procedure relative to the influence of the cuff is great. Thus interviewing the patients offers a measure of the incidence of PST but cannot explain the underlying cause.

Postoperative sore throat is caused by many different factors, of which the tracheal tube cuff is one. To minimize the effects of the cuff in short 
term intubation the pressure and the contact area should be reduced as much as possible. A high volume cuff can be constructed either as a long cuff with a small diameter or a short cuff with a large diameter. To maintain low pressure characteristics the diameter to which the cuff is preformed must exceed the diameter of the trachea, consequently cuff pressure remains zero until contact is made with the tracheal wall. Further inflation increases cuff pressure, representing the pressure of the cuff on the tracheal wall. A short cuff with a large diameter produces low pressure characteristics and a small contact area. In this respect the nomenclature high volume low pressure is misleading - and should preferably be high diameter-low pressure.

1. Lомноцт, N. A new tracheostomy tube. Cuff with controlled pressure on the tracheal mucosa membrane. Acta Anaesth. Scand. 11: 311 (1967).

2. LINDHOLM, C-E. \& CARROLL, R.G. Evaluation of tube derformation pressure in vitro. Crit. Care Med. 3: 196 (1975).

3. NoRDIN, U. The trachea and cuff-induced tracheal injury. An experimental study on causative factors and prevention. Acta Otolaryngol. Suppl. 345 (1977a)

4. STENOvist, O. Endotracheal intubation trauma. An experimental evaluation of pressure induced ischemia, tube-laryngeal wall pressures and a clinical study on the ventilatory properties of narrow tubes. Dissertation, Gothenburg University, Sweden, (1979).

5. WOLFSON, B. Minor laryngeal sequelae of endotracheal intubation. Brit. J. Anaesth. 30:326 (1958).
6. Hartsell, C.J. \& Stephen, C.R. Incidence of sore throat following endotracheal intubation. Can. Anaesth. Soc. J., 11, 3: 307-312 (1964).

7. LOESER, E.A., ORR, D.L. II., BENNETt, G.M. \& STANLEY, T.H. Endotracheal tube cuff design and postoperative sore throat. Anesthesiology 45, 6: 684-697 (1976).

8. Loeser, E.A., Machin, R., Colley, J, OrR, D.L. II., BenNetT, G.M. \& STaniey, T.H. Postoperative sore throat - importance of endotracheal tube conformity versus cuff design. Anesthesiology 49, 6: 430-432 (1978).

9. Loeser, E. A. Stanley, T.H. Jordan, W. \& MACHIN, R, Postoperative sore throat: influence of tracheal tube lubrication versus cuff design. Can. Anaesth. Soc. J. 27: 156 (1980)

10. Grillo, H.C., CoOper, J.D., GefFin, B. \& Pontoppidan, H. A low-pressure cuff for tracheostomy tubes to minimize tracheal injury. A comparative clinical trial. J. Thorac. Cardiovase. Surg. 62, 6: 898 (1971).

11. NoRdin, U., ENGSTRÖM, B. \& LiNDHOLM, C-E. Surface structure of the tracheal wall after different durations of intubation. Acta Otolaryngol. Suppl. 345 (1977b).

12. Romanus, M., Stenquist, O., Haluamäe, H. \& SeIfert, F. Pressure-induced ischemia. An experimental model for intravital microscopic studies in hamster cheek pouch. Eur. Surg. Res. 9: 444-459 (1977).

13. Stenqvist, O., \& BagGe, U. Cuff pressure and microvascular occlusion in the tracheal mucosa. Acta Otolaryngol. 443 (1979b).

14. Stanley, T.H., Kawamura, R. \& Graves, $O$ Effects of nitrous oxide on volume and pressure of endotracheal tube cuffs. Anesthesiology 42 . 637 (1974).

15. Revenäs, B. \& Lindholm, C-E. Pressure and volume changes in tracheal tube cuffs during anaesthesia. Acta Anaesth. Scand. 20: 321-326 (1976).

\section{RÉsumé}

La littérature récente sur le sujet des maux de gorge à la suite d'une anesthésie avec intubation trachéale fait état d'une incidence moindre de cette complication lorsque l'on emploie des tubes à ballonnets à petit volume et haute pression plutôt que ceux à grand volume et basse pression.

Dans ce travail, on a utilisé des méthodes d'évaluation des maux de gorge semblables à celles déjà publiees. Cinquante six patients soumis à une chirurgie abdominale élective ont été intubés, au hasard, avac un tube trachéal à ballonnet à bas volume et haute pression ou à haut volume et basse pression. Les malades ont tous été visités le lendemain de l'intervention par un anesthésiste qui n'était pas au courant du tube utilisé et qui leur a demandé directement $s$ 'ils avaient mal à la gorge. $L$ 'incidence des maux de gorge avec les ballonnets à grand volume et basse pression était de 41 pour cent alors qu'elle était de 55 pour cent avec ceux a petit volume et haute pression. Ces résultats, quoique non statistiquement significatifs tendent à contredire ceux déjà publiés.

$L$ 'incidence des maux de gorge post-opératoires est très variable selon que l'on pose des questions directes ou indirectes aux patients; on retrouve également des variations entre les études utilisant le même genre de questionnaire. Il y a donc lieu de remettre en questions les méthodes utilisées pour évaluer l'influence du type de ballonnet sur les maux de gorge post-operatoires. Le mal de gorge post-opératoire est un symptôme qui peut relever de plusieurs facteurs, tels la technique d'intubation, l'usage d'un stylet ou de lubrifiant. L'incidence de maux de gorge post-opératoires ne reflète pas nécessairement un dommage causé par le ballonnet du tube trachéal. 